\title{
Farm Prices and the Green Revolution: Some Reflections on the Performance of Private Agricultural Markets in Pakistan
}

\author{
FAIZ MOHAMMAD*
}

Private agricultural marketing systems in developing countries are sometimes considered incapable of handling rapid growth in farm produce with adequate reward to the producer. As such, they could discourage improvements in farm productivity. This paper shows that this is not necessarily so in Pakistan. During the Green Revolution of the Sixties, when, owing to cultivation of HYVs, total production of wheat and (coarse) rice increased significantly, the marketing system facilitated the farmer's search for a desired price. More traders entered the trade, and increased competition among them enabled the farmer to secure better prices for his wheat and rice crops. The trader's margin at different stages of marketing also went down during the Green Revolution period, signifying an improvement in the performance of agricultural markets.

\section{INTRODUCTION}

In Pakistan, as in many other developing countries, the performance of traditional (private) agricultural marketing system is seriously debated. Private agricultural markets, which played a major role in the handling of farm produce up to the Sixties in this country and which are now being gradually replaced by public-sector corporations, are blamed for structural imperfections and for problems demanding

*The author is Research Economist at the Pakistan Institute of Development Economics (PIDE), Islamabad. This paper is an extended and improved version of a chapter in his Ph.D. dissertation written at Simon Fraser University, Canada, in 1983, and of a paper presented at the First Annual General Meeting of the Pakistan Society of Development Economists, held at Islamabad in March 1984. He is especially indebted to Professor Mahmood Hasan Khan, his dissertation supervisor, for guidance and help. He also wishes to thank Professor Dennis Maki and Don J. Devoretz of Simon Fraser University for their valuable suggestions that led to an improvement of this paper. Special thanks are due to Professor Syed Nawab Haider Naqvi for his invaluable suggestions and constant encouragement. Dr. Abdul Salam of the Agricultural Prices Commission, Islamabad, made useful comments on an earlier draft of the paper. Helpful suggestions and comments were also received from Drs Sarfraz K. Qureshi, M. Ghaffar Chaudhry, Aftab Ahmad Cheema and Muhammad Hussain Malik. The author wishes to thank all of them for their help. Finally, he is greatly indebted to Mr. S.H.H. Naqavi for his invaluable editorial help and stylistic improvements. However, for any remaining errors and omissions, the author alone is responsible. 
direct government intervention in their functions $[21 ; 26 ; 27] .^{1}$ On the other hand, there are studies which show that these markets have performed their functions "reasonably well" and therefore the government role in this area should be limited only to removing the imperfections created by a poor infrast ructure $[11 ; 12 ; 22]$.

The debate on this subject is far from over. The existing literature $[2 ; 3 ; 24$ 25], however, does not cover several interesting aspects of agricultural marketing in Pakistan. One of them is the ability of the system to adopt new technology and to accommodate a rapid growth in agricultural productivity without leaving "harmful" effects on the consumer or on the farmer. Since it is crucial for the farmer in particular to benefit from his innovations at least as much as the other market participants do, a marketing system which allows him such opportunities can be considered as a well-performing system. ${ }^{2}$

Against this background, the present paper attempts to study the nature of the farmer's market-determined gains in Pakistan from the introduction of HighYielding Varieties (HYVs) of wheat and (coarse) rice in the late Sixties, the period of the Green Revolution $[1 ; 4 ; 8 ; 9]$.

Although the critics of the Green Revolution are yet to be convinced that this "revolution" was as "green" as is popularly believed, one certainly finds the increase in yield per acre of wheat and (coarse) rice during this period as something unprecedented in Pakistan's agriculture. ${ }^{3}$ Owing to the introduction of new varieties, the yield per acre of wheat increased from $330 \mathrm{~kg}$ in $1966-67$ to $435 \mathrm{~kg}$ in $1967-68$ (i.e. by $32 \%$ ) and to $473 \mathrm{~kg}$ in $1969-70$ (i.e. by $43 \%$ as compared to the 1966-67 figure). The yield per acre of rice (all varieties), on the other hand, in creased from $393 \mathrm{~kg}$ in $1966-67$ to $439 \mathrm{~kg}$ in $1967-68$ and to $533 \mathrm{~kg}$ in $1968-69$ (i.e. by $36 \%$ as compared to the $1966-67$ figure). ${ }^{4}$

The total production and the marketable surplus of wheat and rice also increase significantly during the Green Revolution period $[16 ; 17 ; 20]$. The increase in the marketable surplus was bound to affect the marketing conditions related to the transportation and storage of commodities and, therefore, the price received by

${ }^{1}$ See Mohammad [12, p. 1] for major problems of private agricultural markets in Pakistan as pointed out in the existing literature.

${ }^{2}$ Smith [28] regards this as one of the most important criteria to evaluate the performance of agricultural markets in less developed countries. For other criteria, see Jones [6;7] and Lele [10]. Also see Harriss [5] and Timmer [29] for critiques of the studies evaluating the performance of agricultural markets in different countries.

${ }^{3}$ See Griffin [4] and Khan [8;9] for a critical evaluation of the Green Revolution phenomenon in Pakistan.

${ }^{4}$ See Mohammad [12, p. 155] for details of these figures. Figures on IRRI rice only were not available for the year $1966-67$ so that a comparison with the yields in later years was not possible. Data on 'all varieties' are therefore used here for this purpose. the farmer. Moreover, in Pakistan, where there is more than one level of agricultural marketing and where the farmer's participation at a particular market-level depends on the marketable surplus he holds, an increase in farm productivity is likely to alter the environment within which an exchange between the farmer and the trader takes place. The basic premise of this paper is that as the marketable surplus of the farmer increased during the Green Revolution period, he searched for his desired price more than ever before. This change in his behaviour, coupled with the relatively improved transport facilities and increased competition among traders, allowed better prices of wheat and rice to the farmer.

To study this effect of the Green Revolution on the farmer's price and on market performance the paper is divided into four sections. Section I presents a brief introduction to private agricultural marketing in Pakistan as a background to the main body of the paper. In Section II, the changes in marketing conditions induced by the Green Revolution phenomenon and their possible effect on farm prices have been conceptualized. The methodology and analysis of the empirical findings relating to changes in prices and marketing margins of traders are given in Section III. In the final section, we present a summary and major conclusions of this study.

\section{AGRICULTURAL MARKETS IN PAKISTAN}

From among the marketing channels through which a farm produce passes before reaching the consumer in Pakistan, there are three which can be distinguished from one another on the basis of the place of marketing and the type of traders involved. They are (a) village markets; (b) primary wholesale markets; and (c) terminal markets. ${ }^{5}$ A brief description of these markets is given below.

\section{(a) Village Markets}

These markets are situated close to farmgate. In some cases there are welldefined areas where farmers and local traders, known as beoparis, meet regularly to settle transactions, but in most cases the beopari visits farms himself and buys marketable surplus directly from the farmer. The quantities he thus acquires are taken to city markets where he expects to earn some "profit" over and above his

${ }^{5}$ For a detailed description of various agricultural marketing channels in Pakistan, see Mohammad [12] and Cornelisse [2]. Private agricultural markets used to handle almost all the marketable surplus of major farm outputs except rice in the Fifties and the Sixties. However, owing to the heavy procurement of wheat by the government in recent years, their role has significantly decreased. Nevertheless, they still play a considerable role in holding farm products at different stages. For estimates of the proportion of farm outputs handled by private markets in recent years, see Cornelisse [2], Cornelisse and Naqvi [3], and [19]. 
handling costs. Village markets were important in the early years of Pakistan, but recently, owing to improved transport facilities, urban markets, known as primary wholesale markets, have become more important. ${ }^{6}$

\section{(b) Primary Wholesale Markets}

Agricultural markets are usually located in district towns or major subdivisional towns such as Jaranwala in Faisalabad district. These markets are the main assembly points for the marketable surplus of the areas surrounding them. Both farmers and village traders bring their marketable surplus here, which is disposed of usually through the commission agent, locally known as arhti. The major trader, locally known as pucca arhti, who also acts as a wholesaler and an agent of traders in other markets, buys most of the quantities brought in these markets. The katcha ärhti, on the other hand, generally acts as a middleman between the seller and the buyer (who could be a wholesaler, an agent of a mill or a city consumer).

These markets are usually located in specially marked areas in cities and enjoy most of the modern facilities for conducting business, such as telephone and fast modes of transportation (trucks and railways), which are not available in village markets. Arrangements also exist here for settling disputes over pricing and weighing of produce, market charges and other marketing practices. A market committee, created under the Agricultural Produce Market Act of 1939, oversees the activities of functionaries in each market. The traders are required to keep records of their transactions and report them to the respective market committee.

Since these markets are generally better organized compared with the village markets, pricing prospects for farmers are also better here.

\section{(c) Terminal Markets}

All those markets to which the marketable surplus not absorbed by village markets or primary wholesale markets ultimately finds its way are known as terminal markets in Pakistan. They are generally situated in large urban centres. Karachi, Quetta, and Rawalpindi are some of the examples of this type of markets. Traders in terminal markets are mainly wholesalers who supply foodgrains to mills for processing and to retailers. The majority of them are pucca arhtis who buy from other markets through their agents or directly when produce is brought to them from other regions. These markets are the best equipped in the country in terms of physical facilities. The Karachi market, being located in a port city, is also linked to foodgrain markets in other countries.

${ }^{6}$ In a survey conducted by him in 1981 , Mohammad [12] found farmers, particularly the large ones, selling a major proportion of wheat, rice and gram to primary wholesale markets.

\section{FARM PRICES AND THE GREEN REVOLUTION: PROBLEMS AND PROSPECTS}

With the coming of the Green Revolution, Pakistan's agricultural sector, which until then had been close to the subsistence level, started producing a handsome amount of surplus for other sectors. It was, however, feared that the increased supply of agricultural produce in the market would depress the net price received by the farmer. There were at least three reasons for such fears. Firstly, the lower-level markets (i.e. those at the village and primary wholesale levels) in which the farmer usually sold his produce were believed to be lacking in facilities for handling additional supplies. Thus, the farmer, who usually has little "holding capacity" and poor knowledge of marketing conditions, could be compelled to accept inferior prices to "get rid" of his supplies. Secondly, agricultural markets in general and the lowerlevel markets in particular were practically closed to international trade, which otherwise could have absorbed additional supplies and relieved the pressure on domestic markets. Pakistan used to import wheat and (coarse) rice only through official agencies. The grains were then sold to the consumer through a traditional 'rationing system' at prices often less than those in the open market [3]. There was very little change in that policy during the Green Revolution period, so that private domestic markets handled most of the additional supplies. ${ }^{7}$ Thirdly, although the government used to announce procurement prices of wheat and rice, it did not procure any significant quantity to absorb the additional supplies. ${ }^{8}$ The purpose of the procurements was primarily to sustain the 'rationing system' rather than to regulate the open-market prices. Moreover, the official prices were generally less than those in the open market, and unless they were raised to match the latter, the farmer had little incentive to sell to the official agencies. In this way private markets were left to play a major role in determining the prices to be received by the producer of additional marketable surplus.

${ }^{7}$ This is not to say that there were no changes at all in the imported quantities of these commodities during this period. Imports of wheat in particular have been fluctuating from year to year, probably in response to changes in the domestic supply conditions. However, on the average, there was no significant difference between the level of imports from 1967-68 to 1970-71 (i.e. the Green Revolution period) and that of the previous five-year period. The average yearly import of wheat during the former period was 1341,000 tonnes whereas for the latter it was 1356,000 tonnes. In the case of (coarse) rice, the imports during the $1960-61-1965-66$ period amounted to 65,000 tonnes whereas during the $1967-68-1970-71$ period, they totalled 81,000 tonnes [15]. These two figures are also not very different from each other.

${ }^{8}$ The government used to procure only a tiny fraction $(1.0 \%)$ of total production of wheat till 1969-70. In 1969-70, it, for the first time, procured a large proportion (9.5\%) of total production. This might have improved the pricing prospects for the farmer. As regards (coarse) rice, the government procured practically no amount till 1970-71 [11]. The purpose of these procurements was again to sustain the rationing system. 
Now the question is, how well was this role played by the markets? This question can be answered probably in more than one way but here we have tried to answer it by first pointing out some of the positive changes which occurred in those markets in response to the new situation and then by studying the likely impact of those changes on farm prices and marketing margins of traders.

\section{(a) Green Revolution and Changes in Marketing Conditions}

While the increased marketable surplus placed an additional burden on the existing transport and storage facilities, agricultural markets in Pakistan seem to have borne this by improving the marketing environment within which the price formation process takes place. There are at least three areas related to agricultural markets where the positive changes which took place might have actually brightened the pricing prospects for the farmer during the Green Revolution period.

First of all, it has been observed that both at the village-level and at the primary-wholesale-level markets, the number of traders and 'commission agents' increased significantly during the 1967-68 - 1970-71 period. Based on data from 13 major agricultural markets in Pakistan, Mohammad [11, p. 56] found that, on average, the number of ärhtis (commission agents) in these markets increased from 98 in $1965-66$ to 133 in $1967-68$ and to 154 in 1968-69 (an increase of 57\% compared to the 1965-66 figure). This was the biggest ever increase in the number of traders in these markets, and was perhaps due to two major developments: (i) the increased volume of marketable surplus expanded trade at each level and thus attracted more traders into the business; (ii) improved farm productivity and introduction of farm mechanization during that period released some of the family labour from work on farms. Some of the labour so released was likely to engage in alternative economic activities, particularly in trading in farm products and cattle. Other things being equal, the increase in the number of traders tended to enhance competition among the traders and to improve pricing prospects for the farmer.

Secondly, in the Sixties there was also a great jump in the number of tractors in rural areas. 9 The tractors, besides increasing farm power, greatly improved transportation facilities for the farmer. Tractor-trollies widely replaced traditional and slow means of transportation and made access to market easier and faster.

Finally, probably one of the most important changes which the Green Revolution induced in the agricultural marketing conditions was that with his large marketable surplus the farmer became more selective than before about both the time and the place for selling his produce. This change is reflected not only in the

${ }^{9}$ Total number of tractors, which were only 3642 in $1959-60$, increase to 17753 in 1966-67 and to 28535 in 1970-71. Their numbers have continued to increase since then but at a relatively slow pace $[13]$. usual remark of the functionaries in these markets that "these days the farmer has become smarter than before", but also in a number of studies $[3 ; 11 ; 18]$ which find the farmers selling a major share of their produce to primary-wholesale markets rather than to their traditional buyers, the village beoparis. ${ }^{10}$

The main reason for this change appears to be that with large marketable surplus the farmer could afford to make extra search for a desired price. In countries like Pakistan, where there are different levels of markets, the typical marketing behaviour of farmers is that those with very small marketable surplus prefer to sell at the lower-level markets even if they receive somewhat lower prices. It looks like a rational decision as taking small quantities to higher-level markets may not be profitable at all. However, with the increase in marketable surplus, he can afford to choose both a different location and a different time for the disposal of his produce. This has important implication for the net price received by the farmer. First of all, to the farmer who for the first time takes his supplies to an upper-level market this is not simply a change in the venue of his sale but an important improvement in his marketing approach. By interacting with advanced markets he can learn more about transport, storage and credit facilities and plan the disposal of his produce in a much better manner. Secondly, whether the move by the farmer to take his supplies to an upper-level market is real or potential, in both cases the trader in the lower markets is expected to offer him better price than before because only in this way can he retain his share in the business. This he can do either by cutting down his own marketing margin or by minimizing his business costs.

In view of these qualitative improvements in the marketing conditions, it is quite possible that the farmer received better prices than before when his output of wheat and rice increased significantly during the Green Revolution of the late Sixties. To examine the nature of the prices received by the farmer in this period, we turn to Section III.

\section{INTERTEMPORAL COMPARISON OF FARM PRICES AND MARKETING MARGINS}

Methodology

Two approaches have been used to study the behaviour of farm prices during the Green Revolution period: (i) since the main interest of this paper was in seeing if there was an increase or decrease in the net prices received by the farmer, "farm

${ }^{10}$ Mohammad [11] found that in 1979-80 the share of the markets other than the village markets was 59 percent in wheat trade and 63 percent in the rice (paddy) trade. Cornelisse and Naqvi [3] observed that in 1981-82 the village traders handled only 33 percent of wheat surplus whereas the rest was disposed of through other channels. 
prices" of wheat and (coarse) rice during the 1967-68 - 1970-71 period were compared with those in the preceding years, and (ii) since one of the important determinants of the net price received by the farmer is the magnitude of traders' margins at different levels of marketing, estimates of such margins for different years were obtained to make an intertemporal comparison. Methods of estimating these statistics are explained below.

Farm Prices

In an ideal situation, one should compare the actual (farm-level) prices during and before the Green Revolution period to see if the farmer benefited from the increase in agricultural productivity. Unfortunately, this could not be done owing to data constraints in Pakistan. Secondary data on 'monthly average wholesale prices' for selected markets, as reported in [14], were therefore used for this purpose. ${ }^{11}$ Subtracting farm-to-market "handling costs" from those prices, "net prices" were obtained which might be the closest to the prices actually received by the farmer. Those prices were then deflated by monthly Wholesale Price Index of the respective month to arrive at the "real prices". ${ }^{12}$

Based on these data, two types of estimates were obtained for making an intertemporal comparison of prices. In the first case, prices of all the months in a year were used to compare trends in prices in two time periods (viz. before the Green Revolution and during the Green Revolution). In the second case, prices relating to 'harvesting months' only (hereafter harvest prices) were used in studying these trends. The harvest prices $\left(P_{h}\right)$ could also enable us to see if the improvement in the marketing conditions also had any effect on prices in the harvesting months, the period in which the farmers' bargaining position is traditionally believed to be weak because of his limited holding capacity [10]. Accordingly, taking monthly data for wheat from January 1955 to June 1971 and for (coarse) rice from January 1960 to June 1971, regression relationships were obtained between the prices of a commodity in a market, the time variable $(T)$ and a dummy variable $(D)$. The dummy variable was assumed to be equal to one from January 1967 to June 1971 and to zero for earlier months.

Now, if the coefficient of the dummy variable $(D)$ takes a significantly positive value, one may conclude that prices improved during the Green Revolution period in comparison to those in the earlier periods and vice versa.

${ }^{11}$ Since the purpose of the paper was to examine the behaviour of farm prices in different marketing levels, estimates were obtained at the individual market level rather than at provincia or national level. The choice of the markets studied here was mainly based on the availability of continuous time-series of price data for a particular market. On this criterion, only 13 markets could be selected, the list of which is given in Table 1.

${ }^{12}$ Other deflators, such as GNP deflators, were also tried. However, the results did not change significantly.
A similar set of estimates was also obtained by using harvest prices $\left(P_{h}\right)$ for the months of May, June and July for wheat, and for those of November, December and January for rice.

Formally, the estimated equations can be expressed as follows:

$$
\begin{aligned}
& P_{i t}=a o+a_{1} T+a_{2} D+e \quad \ldots \ldots \\
& P_{h_{i t}}=b o+b_{1} T_{h}+b_{2} D^{\prime}+u \quad \ldots \ldots
\end{aligned}
$$
where

$P_{i t} \quad=$ Average monthly wholesale prices of an $i$ th commodity in any market at time ' $t$ ' minus farm-to-market handling costs, divided by the Wholesale Price Index (WPI) of the relevant month;

$P_{h_{i t}} \quad=P_{i t}$ of the harvesting months only;

$D^{\prime} \quad=$ Dummy variable, which is equal to one for harvesting months of the years from 1967 to 1971 , and to zero otherwise;

$a_{1}$ and $b_{1}$ are the coefficients of trend varibles (which may be positive or negative depending on how prices of commodities under study behaved in compari son to Wholesale Price Index); and

$a_{2}$ and $b_{2}$ are the coefficients of dummy variables $D$ and $D^{\prime}$ respectively. Their positive values would indicate that real prices of wheat and rice went up during the Green Revolution period.

To estimate equations (1) and (2), data on prices were taken from [14], whereas for handling costs between village and primary wholesale markets data were computed from more than one source. ${ }^{13}$

\section{Marketing Margins}

Two types of margins were calculated for determining the changes in marketing conditions during the Green Revolution period. They are : (a) Combined margins of the wholesaler and the retailer; and (2) storage margins.

To arrive at the margins of the first category, the most suitable method would have been to calculate them separately for every marketing stage between the farme and the consumer. This required data on the selling and buying prices at each stage but unfortunately they were not available in Pakistan. Alternatively, data on whole sale prices $(W P)$ and retail prices $(R P)$ for a number of primary markets were avail able and they were used to calculate the "gross margins" $(G M)$ of the wholesaler and

${ }^{13}$ The main sources used were Mohammad [11;12], Qureshi [2], Rashid [24] and Siddiqui [27]. Handling costs included costs of weighing and loading at the farm, transport cost, municipal taxes, costs of unloading in market, 'on-the-way' losses, cleaning costs, and agents' commission. For their details, see Mohammad $[11 ; 12]$ 
the retailer taken together. Using data on wheat and rice prices in major agricultural markets, absolute magnitude of $G M$ was calculated as ${ }^{14}$

$$
G M=(R P-W P) \quad \ldots
$$

$$
\cdots
$$

and as a percentage of wholesale prices,

$$
(R G)=(G M / W P) \times 100 \quad \ldots
$$$$
\cdots
$$

As regards storage margins, once again no systematic data from primary sources were available to help us to calculate them. Secondary data on wholesale prices were, therefore, used to calculate what may be called off-season changes in prices. Subtracting storage costs from these "changes", one can get the margins earned by the stock-keeper. In the absence of the actual data on storage margins, this was perhaps one of the most suitable measures one could use here. ${ }^{15}$ The method of estimating these margins is formally stated below.

$$
\begin{aligned}
& \text { GOC }=\sum_{t=1}^{T} \frac{\left(P_{t}-P_{h}\right)}{T} \\
& \text { NOC } \quad=\sum_{t=1}^{T} \frac{\left.\left(P_{t}-P_{h}\right)-\left(S C_{t}\right)\right]}{T} \\
& \text { SC }=(\text { Storage cost })=(R+I+L+D) \\
& \text { RGOC }=\left(\text { GOC } / P_{h}\right) \times 100 \\
& \text { RNOC }=\left(N O C / P_{h}\right) \times 100
\end{aligned}
$$$$
\cdots
$$$$
\cdots
$$$$
\cdots
$$$$
\text { . } \quad \cdots
$$$$
\cdots
$$$$
\cdots
$$$$
\ldots
$$

and $t=1,2, \ldots \ldots \ldots \ldots \ldots$

In the above equations, GOC and $N O C$ respectively denote "Gross Off-season Change" and 'Net Off-season Change' in the price of a commodity in any market in a particular year; $P_{t}$ stands for the average wholesale price in a market in the off-season

${ }^{14}$ Gross margin includes both handling costs and the trader's margin. Therefore, in principle one should exclude handling cost from the gross margin to arrive at "net margin". But owing to non-availability of time-series data on handling costs for this aspect of marketing, net margins could not be calculated. Care should, therefore, be used in interpreting these estimates.

${ }^{15}$ It is perhaps an impossible task to find the actual storage margins earned by private traders as hardly anyone is willing to reveal information concerning his storage operation. Many researchers, including the present author, tried to gather information on this aspect of private markets but failed. See also Lele $[10]$ on this. months, $t$ (from August to April for wheat, and from February to October for rice); and $P_{h}$ is average wholesale price in a market in the 'harvesting months', $h$ (from May to July for wheat, and from November to January for rice). Storage costs were calculat ed as the sum of rent $(R)$, opportunity cost of the capital invested $(I)$, losses in storage $(L)$, calculated as one percent of the value of the stored commodity, and depreciation of bags and other material used in storage $(D)$. The estimates of storage costs were obtained on a monthly basis. ${ }^{16}$ The data on wholesale prices were once again taken from [14] whereas the storage costs were estimated on the basis of the information from Mohammad [11; 12], Qureshi [21] and Siddiqui [27] .

\section{Empirical Results and their Analysis}

Farm Prices

The Ordinary Least Squares (OLS) estimator was found suitable for estimating equations 1 and 2 . The results of this estimator are presented in Tables 1 and 2 for wheat and rice respectively. The salient features of these results are discussed below.

1. Whether one takes 'general prices' (i.e. the prices for all the months in a year) or 'harvest prices', the results indicate that the real prices of wheat and rice in most of the primary wholesale markets moved significantly upward from their trend values during the Green Revolution period. The coefficients $a_{2}$ and $b_{2}$ for rice prices are significant at 5 percent in all the cases except in that for Gujranwala. It appears that since Gujranwala rice prices have been under government control they responded little to the changes in the private-market situation.

The coefficients for wheat prices are also generally significant but are either insignificant or negative in the cases of Karachi, Lahore and Rawalpindi markets. The negative coefficients imply that real prices might have declined during the Green Revolution period in those markets. This is not an unexpected result as the Green Revolution phenomenon was expected to induce favourable changes more at the lower-level markets than at the upper-level ones. Karachi, Lahore and Rawalpindi are among the upper-level markets in Pakistan.

2. A jump in prices during the Green Revolution period appears to have been greater for rice than for wheat. This may have happened because, unlike wheat, rice is principally grown for market rather than for domestic consumption. The farmer is

${ }^{16}$ Calculations of GOC and NOC were based on the assumption that traders buy stored commodities in the harvesting months and sell them in any month of the off-season period. In every off-season month, there is some change in price compared with the average harvest price This "change" represents the gross off-season change. When the storage cost for the same month is subtracted from the GOC per month, one gets NOC per month. These monthly figures were used to arrive at an average for the whole off-season period of each year. 
Table 1

Relationships between Real Prices of Wheat, the Time Variable and a Dummy Variable, for Selected Agricultural Markets in Pakistan, 1955-56 to 1970-71

\begin{tabular}{|c|c|c|c|c|c|c|c|c|}
\hline \multirow[b]{3}{*}{ Markets } & \multicolumn{4}{|c|}{ Equation using General Prices } & \multicolumn{4}{|c|}{ Equation using Harvest Prices } \\
\hline & \multicolumn{3}{|c|}{ Parameters } & \multirow{2}{*}{ F-Values } & \multicolumn{3}{|c|}{ Parameters } & \multirow{2}{*}{ F-Values } \\
\hline & $\mathrm{a} 0$ & a1 & $\mathrm{a} 2$. & & b0 & b1 & $\mathrm{b} 2$ & \\
\hline Faisalabad & 13.29 & $\begin{array}{c}0.018 \\
(2.71)\end{array}$ & $\begin{array}{r}0.605 \\
(2.05)\end{array}$ & 23.75 & 14.27 & $\begin{array}{c}-0.152 \\
(2.34)\end{array}$ & $\begin{array}{c}3.08 \\
(2.89)\end{array}$ & 8.87 \\
\hline Gujranwala & 13.78 & $\begin{array}{r}0.017 \\
(2.25)\end{array}$ & $\begin{array}{c}0.638 \\
(1.985)\end{array}$ & 21.39 & 14.25 & $\begin{array}{c}-0.13 \\
(2.16)\end{array}$ & $\begin{array}{c}2.51 \\
(2.40)\end{array}$ & 7.22 \\
\hline Hyderabad & 13.17 & $\begin{array}{r}0.019 \\
(2.11)\end{array}$ & $\begin{array}{l}0.546 \\
(1.875)\end{array}$ & 20.87 & 14.88 & $\begin{array}{r}-0.254 \\
(2.21)\end{array}$ & $\begin{array}{c}2.12 \\
(2.18)\end{array}$ & 7.55 \\
\hline Karachi & 14.02 & $\begin{array}{r}0.029 \\
(1.98)\end{array}$ & $\begin{array}{c}-0.296 \\
(0.863)\end{array}$ & 20.03 & 14.18 & $\begin{array}{r}-0.067 \\
(1.18)\end{array}$ & $\begin{array}{c}1.03 \\
(1.14)\end{array}$ & 2.72 \\
\hline Lahore & 13.83 & $\begin{array}{r}0.021 \\
(3.37)\end{array}$ & $\begin{array}{c}-0.372 \\
(1.39)\end{array}$ & 20.66 & 13.54 & $\begin{array}{r}-0.092 \\
(1.66)\end{array}$ & $\begin{array}{c}1.89 \\
(1.61)\end{array}$ & 3.09 \\
\hline Multan & 13.07 & $\begin{array}{r}0.024 \\
(2.74)\end{array}$ & $\begin{array}{r}0.596 \\
(1.98)\end{array}$ & 24.12 & 12.95 & $\begin{array}{r}-0.067 \\
(0.98)\end{array}$ & $\begin{array}{c}2.35 \\
(2.33)\end{array}$ & 6.06 \\
\hline Okara & 12.81 & $\begin{array}{r}0.023 \\
(2.73)\end{array}$ & $\begin{array}{r}0.937 \\
(2.57)\end{array}$ & 25.98 & 13.25 & $\begin{array}{c}-0.128 \\
(2.25)\end{array}$ & $\begin{array}{c}2.55 \\
(2.69)\end{array}$ & 12.67 \\
\hline Peshawar & 13.77 & $\begin{array}{c}0.018 \\
(1.91)\end{array}$ & $\begin{array}{c}0.565 \\
(1.735)\end{array}$ & 18.23 & 14.75 & $\begin{array}{r}-0.238 \\
(3.32)\end{array}$ & $\begin{array}{c}2.10 \\
(1.67)\end{array}$ & 8.57 \\
\hline Rawalpindi & 14.06 & $\begin{array}{r}0.017 \\
(1.54)\end{array}$ & $\begin{array}{c}-0.215 \\
(0.215)\end{array}$ & 18.74 & 14.99 & $\begin{array}{r}-0.219 \\
(4.14)\end{array}$ & $\begin{array}{l}1.86 \\
(1.75)\end{array}$ & 11.27 \\
\hline Sahiwal & 12.95 & $\begin{array}{r}0.026 \\
(2.85)\end{array}$ & $\begin{array}{r}0.896 \\
(2.32)\end{array}$ & 26.01 & 13.48 & $\begin{array}{c}-0.098 \\
(2.76)\end{array}$ & $\begin{array}{c}2.64 \\
(2.16)\end{array}$ & 8.92 \\
\hline Sargodha & 13.03 & $\begin{array}{c}0.021 \\
(2.39)\end{array}$ & $\begin{array}{r}0.786 \\
(1.97)\end{array}$ & 24.65 & 13.77 & $\begin{array}{r}-0.175 \\
(2.67)\end{array}$ & $\begin{array}{c}2.87 \\
(2.04)\end{array}$ & 8.72 \\
\hline Sialkot & 13.08 & $\begin{array}{r}0.022 \\
(2.05)\end{array}$ & $\begin{array}{r}0.695 \\
(1.92)\end{array}$ & 22.14 & 13.58 & $\begin{array}{r}0.056 \\
(1.27)\end{array}$ & $\begin{array}{c}2.74 \\
(2.91)\end{array}$ & 11.98 \\
\hline
\end{tabular}

Source: Computations based on price data from [14], and on other data from Mohammad [11,pp. 267-268].

Note: Prices here refer to average monthly wholesale prices received by the farmer. Figures in brackets are t-statistics. Durbin-Watson statistics, not reported here for economy of space, were generally in the inconclusive range.
Table 2

Relationship between Real Prices of Rice (Coarse), the Time Variable, and a Dummy Variable for Selected Agricultural Markets in Pakistan, 1960 to 1970-71

\begin{tabular}{|c|c|c|c|c|c|c|c|c|}
\hline \multirow[b]{3}{*}{ Markets } & \multicolumn{4}{|c|}{ Equation using Real Prices } & \multicolumn{4}{|c|}{ Equation using Harvest Prices } \\
\hline & \multirow[b]{2}{*}{$\mathrm{a} 0$} & \multicolumn{2}{|c|}{ Parameters } & \multirow{2}{*}{ F-Values } & \multirow{2}{*}{ b0 } & \multicolumn{2}{|c|}{ Parameters } & \multirow{2}{*}{ F-Values } \\
\hline & & a1 & a2 & & & b1 & b2 & \\
\hline Faisalabad & 21.86 & $\begin{array}{c}-0.081 \\
(6.09)\end{array}$ & $\begin{array}{c}6.59 \\
(6.26)\end{array}$ & 21.57 & 22.41 & $\begin{array}{r}-0.466 \\
(3.71)\end{array}$ & $\begin{array}{c}7.69 \\
(3.74)\end{array}$ & 10.47 \\
\hline Gujranwala & 14.54 & $\begin{array}{l}0.048 \\
(.449)\end{array}$ & $\begin{array}{c}-0.539 \\
(0.688)\end{array}$ & 0.294 & 14.82 & $\begin{array}{r}0.030 \\
(0.25)\end{array}$ & $\begin{array}{c}1.84 \\
(1.03)\end{array}$ & 1.27 \\
\hline Hyderabad & 21.01 & $\begin{array}{r}-0.092 \\
(4.75)\end{array}$ & $\begin{array}{r}5.197 \\
(3.63)\end{array}$ & 16.46 & 21.09 & $\begin{array}{r}-0.435 \\
(2.92)\end{array}$ & $\begin{array}{c}6.28 \\
(3.08)\end{array}$ & 8.28 \\
\hline Karachi & 32.56 & $\begin{array}{c}-0.066 \\
(5.28)\end{array}$ & $\begin{array}{r}3.747 \\
(2.39)\end{array}$ & 12.39 & 29.62 & $\begin{array}{c}-0.351 \\
(3.05)\end{array}$ & $\begin{array}{l}2.99 \\
(2.17)\end{array}$ & 6.48 \\
\hline Lahore & 21.48 & $\begin{array}{r}-0.084 \\
(7.11)\end{array}$ & $\begin{array}{c}5.79 \\
(6.65)\end{array}$ & 27.93 & 21.72 & $\begin{array}{c}-0.362 \\
(2.44)\end{array}$ & $\begin{array}{c}3.73 \\
(2.18)\end{array}$ & 10.11 \\
\hline Multan & 21.46 & $\begin{array}{r}-0.086 \\
(7.39)\end{array}$ & $\begin{array}{r}6.068 \\
(7.07)\end{array}$ & 32.34 & 22.83 & $\begin{array}{r}-0.502 \\
(5.02)\end{array}$ & $\begin{array}{c}5.13 \\
(4.37)\end{array}$ & 12.62 \\
\hline Okara & 18.55 & $\begin{array}{r}-0.042 \\
(2.99)\end{array}$ & $\begin{array}{c}5.12 \\
(4.93)\end{array}$ & 17.92 & 15.86 & $\begin{array}{c}-0.58 \\
(1.46)\end{array}$ & $\begin{array}{c}6.96 \\
(4.54)\end{array}$ & 11.23 \\
\hline Peshawar & 25.38 & $\begin{array}{r}-0.163 \\
(5.69)\end{array}$ & $\begin{array}{l}13.75 \\
(6.52)\end{array}$ & 26.23 & 23.46 & $\begin{array}{c}-0.519 \\
(2.56)\end{array}$ & $\begin{array}{c}4.11 \\
(2.25)\end{array}$ & 8.04 \\
\hline Rawalpindi & NA & NA & NA & NA & NA & NA & NA & NA \\
\hline Sahiwal & 21.23 & $\begin{array}{c}-0.072 \\
(5.14)\end{array}$ & $\begin{array}{c}4.95 \\
(4.84)\end{array}$ & 16.57 & 19.41 & $\begin{array}{c}-0.169 \\
(1.53)\end{array}$ & $\begin{array}{c}8.42 \\
(4.99)\end{array}$ & 11.69 \\
\hline Sargodha & 20.69 & $\begin{array}{c}-0.59 \\
(4.52)\end{array}$ & $\begin{array}{c}5.54 \\
(5.64)\end{array}$ & 19.16 & 19.51 & $\begin{array}{c}-0.168 \\
(1.71)\end{array}$ & $\begin{array}{l}6.5 \\
(3.59)\end{array}$ & 8.43 \\
\hline Sialkot & 20.69 & $\begin{array}{c}-0.053 \\
(4.78)\end{array}$ & $\begin{array}{c}7.52 \\
(4.93)\end{array}$ & 20.71 & 17.33 & $\begin{array}{r}-0.281 \\
(2.31) \\
\end{array}$ & $\begin{array}{r}7.28 \\
(4.03) \\
\end{array}$ & 11.39 \\
\hline $\begin{array}{l}\text { Source: } \\
\text { Note: }\end{array}$ & $\begin{array}{l}\text { omputati } \\
\text { p. } 267-26 \\
\text { Prices I } \\
\text { i) Figures } \\
\text { ii) Durbir } \\
\text { in the } \\
\text { v) } \mathrm{NA}=1\end{array}$ & $\begin{array}{l}\text { ns based or } \\
\text { ]. } \\
\text { ere refer t } \\
\text { in brackets } \\
\text { - Watson sta } \\
\text { nconclusive } \\
\text { ot available }\end{array}$ & $\begin{array}{l}\text { n price d } \\
\text { o average } \\
\text { are } t \text {-stati } \\
\text { tistics, no } \\
\text { range. }\end{array}$ & $\begin{array}{l}\text { lata from } \\
\text { monthly } \\
\text { istics. } \\
\text { ot reported }\end{array}$ & $\begin{array}{l}\text { 4]. For } \\
\text { wholesale } \\
\text { here for } \mathrm{e}\end{array}$ & $\begin{array}{l}\text { ther data, } \\
\text { rices rec } \\
\text { onomy o }\end{array}$ & $\begin{array}{l}\text { see Moha } \\
\text { ived by } \\
\text { space, we }\end{array}$ & $\begin{array}{l}\text { mmad [11, } \\
\text { the farmer. } \\
\text { re generally }\end{array}$ \\
\hline
\end{tabular}


therefore generally observed to be relatively more market-conscious when selling his rice crop.

3. The coefficients of trend in prices $\left(a_{1}\right.$ and $\left.b_{1}\right)$ have taken different signs in different cases. These estimates need some interpretation even though the major emphasis of this paper is not on them as such. As regards 'general prices' of wheat, they seem to have increased at moderate rates in all the markets during the study period, as $a_{1}$ is positive in all these cases. However, somewhat paradoxically, estimates of $b_{1}$ indicate that 'harvest prices' for wheat decreased during this period in most of the markets. This may have been partly due to the fact that harvest prices in Pakistan are generally observed to be less than off-season prices, a pattern not necessarily followed by the monthly Wholesale Price Index (WPI). ${ }^{17}$ In this situation, if the Wholesale Prices Index (used as a deflator here) rises continuously over time, the trend in the deflated harvest prices would become negative. As regards the changes in the prices for the period as a whole (i.e. general prices of wheat), there is no special reason why they should have remained systematically less than the changes in the Wholesale Price Indices. Hence, their trend was positive.

Trends in rice prices are also negative in all the markets, implying once again that their nominal values did not rise as much as did the Wholesale Price Index over this period. This may be partly due to the fact that the government involvement has always been more active in rice trade than in wheat trade, with the result that the government was able to keep the changes in rice prices lower than the changes in WPI.

\section{Combined Margins of Wholesalers and Retailers}

These margins were computed for the 1955 - 1971 period for wheat, and for the 1960 - 1971 period for rice for all the markets mentioned earlier. A summary of the estimated figures is presented in Table 3. These estimates indicate that, compared with those for the 1955-60 and 1960-66 periods, average gross margins for the 1967-71 period are significantly lower. The average rate of gross margin in the case of wheat, for example, is 7.02 percent for the 1967-71 period, whereas for the 1955-60 and 1961-66 periods they are 11.48 percent and 10.74 percent respectively. In the case of rice, the average margin for the 1967-71 period was 19.25 percent whereas it was 23.04 percent for the $1960-66$ period. The differences among these rates are significant at the 5-percent level in most cases.

The fall in these margins indicates that the share of those farmers who sold directly to primary wholesale markets in the price paid by the consumer increased

${ }^{17}$ This is not to say that the differences between harvest and off-season prices of these commodities have always been greater than storage costs. For a number of economic reasons, harvest prices could always be less than off-season prices and yet not be as low as to permit systematically an economic profit to the stock-keeper.
Table 3

Intertemporal Comparison of Gross Margins (of the Wholesaler and the Retailer taken together) in Selected Agricultural Markets in Pakistan: 1955-56 - 1970-71

\begin{tabular}{|c|c|c|c|c|c|c|}
\hline \multirow[b]{2}{*}{ Markets } & \multicolumn{3}{|c|}{ Wheat } & \multicolumn{3}{|c|}{ Rice (Coarse) } \\
\hline & $\begin{array}{c}1955-56 \\
\text { to } \\
1959-60\end{array}$ & $\begin{array}{c}1960-61 \\
\text { to } \\
1965-66\end{array}$ & $\begin{array}{c}1967-68 \\
\text { to } \\
1970-71\end{array}$ & $\begin{array}{c}1955-56 \\
\text { to } \\
1959-60\end{array}$ & $\begin{array}{c}1960-61 \\
\text { to } \\
1965-66\end{array}$ & $\begin{array}{c}1967-68 \\
\text { to } \\
1970-71\end{array}$ \\
\hline & & & Perce & tage & & \\
\hline Faisalabad & $13.18^{*}$ & $9.16^{*}$ & 5.48 & NA & $25.52 * *$ & 20.90 \\
\hline Gujranwala & $10.75^{*}$ & $6.93 * *$ & 5.05 & $"$ & $18.85^{* *}$ & 12.27 \\
\hline Hyderabad & $15.75^{*}$ & $10.23^{*}$ & 6.88 & ", & $23.61 *$ & 19.34 \\
\hline Karachi & $10.08 * * *$ & $21.52 *$ & 9.82 & , & $26.52 * * *$ & 24.15 \\
\hline Lahore & 7.88 & $12.62 *$ & 9.81 & ", & $22.45 * *$ & 19.78 \\
\hline Multan & $12.94 * *$ & $12.84 * *$ & 11.62 & ", & $23.14 * *$ & 20.03 \\
\hline Okara & NA & NA & NA & $"$ & NA & NA \\
\hline Peshawar & 6.27 & 7.08 & 7.29 & $"$ & $24.95 * *$ & 20.43 \\
\hline Rawalpindi & $17.29 *$ & 7.19 & 9.07 & ", & $22.05 * *$ & 19.25 \\
\hline Sahiwal & NA & NA & NA & ", & NA & NA \\
\hline Sargodha & NA & NA & NA & $"$ & NA & NA \\
\hline Sialkot & 9.18 & $9.06 * * *$ & 7.99 & $"$ & $20.27 *$ & 15.13 \\
\hline Average & $11.48 * *$ & $10.74 * *$ & 7.02 & $"$ & $23.04 * *$ & 19.25 \\
\hline
\end{tabular}

Source: Computations based on price data from [14].
Notes: (i) The number of stars on any figure indicates the level of significance at which the 1967-71 average is lower than averages of the previous periods. One star stands for the 1-percent level of significance, two stars for the 5-percent level of significance, and three stars for the 10-percent level of significance.

(ii) NA = Data not available. 
during the Green Revolution period. Now, if some degree of interrelationship exists among markets at different levels, then it is possible that the trader's margins at other levels of marketing also fell. ${ }^{18}$ This is so because, other things being equal, a significant difference between the margins in two marketing levels could induce traders to move to that level where margins are high. This process would tend to equalize margins in different markets.

\section{Gross and Net Off-season Changes in Prices}

Using the procedure stated in equations (5) - (9), we estimated the rates of 'Gross Off-season Change' (RGOC) and Net Off-season Change (RNOC) in wholesale prices for all the major markets mentioned earlier. The averages of these estimates for different periods are presented in Table 4. Like the margins of wholesalers and retailers presented above, estimates of RGOC and RNOC also indicate that traders' margins fell during the Green Revolution period.

The average RGOC in the case of wheat, for example, fell from 16.45 percent in the $1955-60$ period to 8.32 percent in the $1967-71$ period. The corresponding figure for the 1960-66 period is 12.29 percent. Similarly, the RNOC figures, which were 2.23 percent during the $1955-60$ period and -.54 percent during the $1960-66$ period, went down to -4.57 percent during the $1967-71$ period.$^{19}$

In the case of rice also, the figures for the 1967-71 period are lower than those for the 1960-66 period. For example, for the 1967-71 period, the RGOC is 11.21 percent and the RNOC is -0.65 percent whereas for the $1960-66$ period the corresponding figures are 15.52 percent and 1.68 percent.

In most of these cases, the estimates for the 1967-71 period were found to be significantly lower than those for the previous periods at the 5-percent level. This fall in storage margin can also be associated with the improvements in marketing conditions induced by the Green Revolution phenomenon. Whereas a systematic jump in marketable surplus enhanced the farmer's holding capacity, his interaction with the upper-level markets improved his understanding of the intertemporal behaviour of the markets. A gradual increase in the storage facilities in the country may also have helped him in this process.

${ }^{18}$ See Qureshi $[22 ; 23]$ for evidence that there exists a high degree of relationship between the prices in the village and the primary wholesale markets in Pakistan.

${ }^{19}$ Negative values of RNOC may appear somewhat odd. But since RNOC, in a way, is a measure of "economic profit", its values could be negative, as a firm usually stays in business as long as it can make some positive "accounting profit" and not necessarily when it makes positive economic profit. 


\section{SUMMARY AND CONCLUSIONS}

The introduction of the High-Yielding Varieties of wheat and rice in the late Sixties was one of the major technological improvements experienced by agriculture in Pakistan. Notable among the qualitative and quantitative changes brought about by this Green Revolution phenomenon were a jump of around 40 percent in per acre yields of wheat and (coarse) rice and a significant increase in the marketable surplus of these two major commodities. The purpose of this paper was to study the extent to which the farmer might have gained from participating in the marketing process with the relatively large quantities of marketable surplus made possible by the High Yielding Varieties. This was one of the many ways to see whether the existing private marketing system helped or hindered technological improvement in the agricultural sector.

The paper first reviewed the environment within which agricultural markets in Pakistan had to face an increased supply of farm produce. Here we found that despite the physical problems which the increased supply might have created for those markets, the markets met the "challenge" successfully by making suitable adjustments within their structures and allowed a better price to the farmer. There was a big increase in the number of traders functioning in them as well as in the number of tractor-trollies making the farmer's access to market quicker and easier. But, more importantly, it was noted that in countries like Pakistan where there are different levels of marketing, viz. village level, primary wholesale level, and terminal level, the farmer's participation in a particular level could change when he has relatively large amount to sell. This may be so because with a large marketable surplus per unit cost of marketing a product usually goes down, and the farmer is encouraged to increase his search for a better price. As a result, he may not only decide to sell his produce in an upper-level market, rather than to a traditional buyer in the village market, but also to select a different time for its disposal. Keeping in view the changed marketing environment, the trader at each level of marketing, particularly at the lower level, is likely to reduce his marketing margin to induce the farmer to stay with his traditional buyer. The net price received by the farmer would increase in this process.

In this paper, different methods were used to capture the above-stated phenomenon. In the first place, through regression estimates it was observed that the real farm prices of wheat and (coarse) rice during the Green Revolution period (1967-71) rose significantly above those in the earlier years. We then estimated 'marketing and storage margins' which in comparison with those in the earlier periods were observed to have fallen during the Green Revolution period. On the basis of these findings one may like to draw the following main conclusions about private agricultural markets in Pakistan.
Firstly, these findings do not support the common view about private agricultural markets in Pakistan that they are incapable of accommodating increases in the marketable surplus with adequate reward to the farmer. Instead, as this paper suggests, by allowing better prices to the farmer these markets could have actually facilitated the adoption of new varieties in the Sixties. This is a sign of their good health, which must be kept in mind while devising any policy for further improving their performance.

Secondly, from these findings one may also conclude that agricultural market ing in a country like Pakistan can not be viewed in isolation from the rest of the agricultural sector. Any change at production level affects the farmer's decision and ability to market his output, and vice versa. Therefore, it is quite probable that an expansion in agricultural productivity also induces favourable changes in the market ing conditions for a crop. Under these circumstances it will be highly desirable for the government to focus on enhancing agricultural productivity even to strengthen the marketing ability of the farmer, rather than on intervening directly in the market ing system and incurring both explicit and implicit costs.

While accepting the above conclusions, however, a few reservations may be kept in mind. Firstly, it is important to note that most of our estimates were based on secondary data, the soundness of which is always open to question in countries like Pakistan. Secondly, for certain aspects, such as trader's margins in village markets, even secondary data were not available. As a result, the analysis here was not as broad-based as it could have been.

Finally, it should be emphasized that the observed improvements in farm prices during the Green Revolution period, while mainly brought about by induced changes in private marketing conditions, may well have been contributed by some other factors also. The complex nature of the price formation process is likely to yield to many factors, not all of which can be quantified. It is therefore possible that prices during the Green Revolution improved also due to forces outside the private agricultural markets in Pakistan.

\section{REFERENCES}

1. Chaudhry, M. G. "Green Revolution and Redistribution of Rural Incomes: Pakistan's Experience”. Pakistan Development Review. Vol. XXI, No. 3. Autumn 1982. pp. 173-205.

2. Cornelisse, Peter A. "Wheat-market Flows in the Punjab". Pakistan Development Review. Vol. XXIII, No. 1. Spring 1984. pp. 65-80.

3. Cornelisse, Peter A., and Syed Nawab Haider Naqvi. The Anatomy of the Wheat Market in Pakistan. Rotterdam: Erasmus University/Islamabad: Pakistan Institute of Development Economics. 1984. 
4. Griffin, Keith. The Political Economy of Agrarian Change. Cambridge, Mass. (USA): Harvard University Press. 1972.

5. Harris, Barbara. "There is Method in my Madness: Or Is it Vice Versa? Measuring Agricultural Market Performance". Food Research Institute Studies. Vol. XVII, No. 2. 1979.

6. Jones William O. Marketing Staple. Food Crops in Tropical Africa. Ithaca, N.Y.: Cornell University Press. 1972.

7. Jones, William O. "Regional Analysis and Agricultural Marketing Research in Tropical Africa; Concepts and Experience". Food Research Institute Studies. Vol. 13, No. 1. 1974.pp. 3-28.

8. Khan, M. H. The Economics of Green Revolution. New York: Praeger Publishers. 1975.

9. Khan, M. H. "Green Revolution and Redistribution of Rural Incomes: Pakistan's Experience - A Comment". Pakistan Development Review. Vol. XXII, No. 1. Spring 1983. pp. 47-56.

10. Lele, U. J. Foodgrain Marketing in India: Private Performance and Public Policy. Ithaca, N.Y. : Cornell University Press. 1971.

11. Mohammad, Faiz. "An Analysis of the Structure and Performance of Agricultural Markets in Pakistan". Unpublished Ph.D. dissertation, Simon Fraser University, British Calumbia, Canada. January 1983.

12. Mohammad, Faiz. "Pricing Efficiency in Agricultural Markets in Pakistan". Islamabad: Pakistan Institute of Development Economics. 1977. (Research Report No. 106)

13. Naqvi, Syed Nawab Haider, et al. The P.I.D.E. Macro-econometric Model of Pakistan's Economy. Islamabad: Pakistan Institute of Development Economics. 1983.

14. Pakistan. Agricultural Marketing Adviser. Markets and Prices. Karachi. (Yearly Publications from 1955-56 to 1971-72)

15. Pakistan. Ministry of Finance. Economic Adviser's Wing. Pakistan Economic Survey. Islamabad. (Selected Issues from 1960-61 to 1971-72)

16. Pakistan. Ministry of Finance. Statistics Division. Pakistan Statistical Yearbook. Islamabad. (Issues for 1975-76, 1977, 1979 and 1980)

17. Pakistan. Ministry of Food and Agriculture. Agricultural Statistics of Pakistan. Islamabad. (Issues for 1970, 1975 and 1980)

18. Pakistan. Ministry of Food and Agriculture. Survey Report on Marketing of Wheat in Pakistan. Islamabad. 1979.

19. Pakistan. Ministry of Food and Agriculture. Survey Report on Utilization of Agricultural Commodities. Islamabad. (Issue for 1979)

20. Punjab. Planning and Development Department. Bureau of Statistics. Development Statistics of the Punjab. Lahore. (Issues for 1968 and 1972)
21. Qureshi, M. Toaha. Estimation of Marketing Margins and Measurement of Seasonal Variation of Selected Agricultural Commodities in Sind Province of Pakistan. Tando Jam, Sind (Pakistan): Sind Agricultural University. 1974.

22. Qureshi, S. K. "The Performance of Village Markets for Agricultural Produce: A Case Study of Pakistan”. Pakistan Development Review. Vol. XIII, No. 3. Autumn 1974. pp. 280-307.

23. Qureshi, S. K. "Reliability of Pakistani Agricultural Price Data". Pakistan Development Review. Vol. XII, No. 2. Summer 1973. pp. 168-180.

24. Rashid, A. Economic Aspects of Distribution Margins. International Comparisons. Lyallpur (now Faisalabad): West Pakistan Agricultural University. 1970.

25. Rashid, A. The State of Agricultural Marketing in Pakistan. Lyallpur (now Faisalabad): West Pakistan Agricultural University. 1970.

26. Sattar, S. et al. Marketing of Agricultural Products in Punjab. Lahore: Punjab Board of Economic Inquiry. 1976.

27. Siddiqui, Sharif Ahmad. Marketing of Agricultural Products in Sind. Tando Jam, Sind (Pakistan): Sind Agricultural University. 1979.

28. Smith, E. D. "Agricultural Marketing Research for Less-Developed Areas". American Journal of Agricultural Economics. Vol. 54, No. 4 (Part I). November 1972. pp 666-70.

29. Timmer, Peter, Review of U. J. Lele's Book. Foodgrain Marketing in India Private Performance and Public Policy, in Economic Development and Cultural Change. Vol. 22, No. 3. April 1974. 